\title{
Simultaneous measurement of food particle selection and clearance rates of planktonic oligotrich ciliates (Ciliophora: Oligotrichina)
}

\author{
Kai Kivi*, Outi Setälä \\ Tvärminne Zoological Station, FIN-10900 Hanko, Finland
}

\begin{abstract}
Oligotrich ciliates are a major microzooplankton component in the northern Baltic Sea during summer. The use of wheat starch particles as a tracer-level food source enabled us to simultaneously evaluate in situ clearance rates and food particle size selection of natural ciliate assemblages. Average clearance rates of 9 ciliates of the genera Lohmanniella, Strobilidium, Strombidium, Tintinnidium and Tintinnopsis on their most favored particle sizes ranged from 1.9 to $11.4 \mu \mathrm{l} \mathrm{cell-1} \mathrm{h}^{-1}$. Particle size selectivity was studied by the use of $\chi^{2}$-based selectivity index. Each species showed a specific particle size preference pattern. The optimal particle size varied from $1.4 \mu \mathrm{m}$ (Strombidium sp. $20 \mu \mathrm{m}$ in size) to $9.8 \mu \mathrm{m}$ (Strobilidium sp. $40 \mu \mathrm{m}$ ). Most species were able to ingest effectively nanoflagellate-size food, but only 2 of the species showed effective grazing on the smallest particles, suggesting a possible ability to utilize bacteria-size prey. The overall ciliate food size spectrum covered the size range of the most abundant food items in the Baltic summer plankton. Among the ciliates investigated, there appears to be 2 different feeding strategies: specialistic and generalistic, where the ciliates either concentrate on feeding on a narrow size range of food organisms, or use food particles of a wide size range, with little or no preferences within this range.
\end{abstract}

KEY WORDS: Ciliates Grazing · Food selection

\section{INTRODUCTION}

Microprotozoans, including ciliates, are recognized as a major component in pelagic food webs (e.g. Azam et al. 1983). Oligotrich ciliates form the bulk of ciliated protozoan biomass in most marine as well as brackish water ecosystems (Beers et al. 1980, Smetacek 1981, Andersen \& Sørensen 1986, Sherr et al. 1986). In the ocean, they are known to be important grazers of nanoplankton populations (Heinbokel 1979, Verity 1986, Burkill et al. 1987, Paranjape 1987, 1990), and in some cases also of bacteria (Sherr \& Sherr 1987, Rassoulzadegan et al. 1988, Sherr et al. 1989). At least some ciliates have shown high selectivity in choosing their food items (Stoecker et al. 1981). In the northern Baltic Sea, oligotrichs of the genera Strombidium,

\footnotetext{
- Present address: National Board of Waters and the Environment, PO Box 250, FIN-00101, Helsinki, Finland
}

Strobilidium, Lohmanniella and Tintinnopsis are the most important microprotozoans (in the 20 to $200 \mu \mathrm{m}$ size range) during the summer months (Kivi 1986). Feeding of the Baltic ciliates is still incompletely studied, although they are suspected to be major consumers of especially nanoflagellates (Jonsson 1986). To a lesser extent they also prey on picoplanktonic organisms (Kuosa 1990) and bacteria (Gast 1985).

A multitude of techniques is available for the study of protozoan feeding. These methods can be roughly divided into 2 main categories, direct and indirect. The former usually make use of different artificial or natural food particles, which are distinguishable in the cell after ingestion, using various microscopy techniques (e.g. Heinbokel 1978a, Jonsson 1986, Sherr \& Sherr 1987, Bernard \& Rassoulzadegan 1990). Related to these methods are those measuring uptake of food labelled with radioactive isotopes (e.g. Lessard \& Swift 1985). These techniques have proved to be most useful in studies of metazoan grazing (e.g. Lampert 1974). 
The latter category uses methods measuring disappearance of particles (or chlorophyll, etc.) due to grazing with time (e.g. Rassoulzadegan \& Etienne 1981). Some other techniques that do not clearly belong to either of the categories mentioned above, like the seawater dilution method of Landry \& Hassett (1982), have also been successfully used to evaluate the impact of protozoan grazing on natural phytoplankton populations.

The approach of our study of ciliate clearance rates and particle size selection is based on direct uptake measurements of wheat starch particles (range from ca 1.4 to $40 \mu \mathrm{m}$ ). The ingested particles are counted and their sizes are measured under a microscope. The particles can be introduced in tracer-level quantities into enclosures containing natural populations of planktonic organisms. The technique is designed to enable simultaneous evaluation of food particle size selectivity and clearance rates of different species in the naturally occurring ciliate community. In this article, the particle size selectivity and in situ clearance rates of 9 different oligotrich species (or species groups) are presented, and the method and results are viewed in comparison with other protozoan grazing studies.

\section{MATERIALS AND METHODS}

Experiments were conducted during the summers of 1987 and 1989. They were performed in the outer archipelago of the Finnish coast in the western Gulf of Finland, in the vicinity of the Tvärminne Zoological Station $\left(59^{\circ} 49^{\prime} \mathrm{N}, 23^{\circ} 17^{\prime} \mathrm{E}\right)$. Data on the tintinnid ciliates are based on 1 experiment from June 1987; all the other experiments were conducted during June and July 1989, when altogether 6 experiments were made, 2 of these at night. Only surface water temperature was measured in the 1987 experiment. In 1989, water temperature (at 0,5 and $10 \mathrm{~m}$ ) and daytime profiles of photosynthetically active radiation (PAR) for the 0 to $10 \mathrm{~m}$ layer were measured.

The starch powder used in preparing the stock solutions was wheat starch of pharmacy quality. Wheat starch was chosen because of its suitable particle shape and size distribution (for instance, corn and potato starch particles proved to be irregularly shaped or too large in mean size). Purified wheat starch consists of spherical or slightly elongated particles, most of which are nano-sized. The starch particle stocks were prepared by first filtering the initial solution $(1.00 \mathrm{~g}$ starch powder $1^{-1}$ Milli-Q-purified water) through a $40 \mu \mathrm{m}$ mesh net filter to remove large particles and clumps. The procedure was repeated, and the $1 \mathrm{l}$ bottle containing the solution was then put on an automatic shaker for ca $1 \mathrm{~h}$ to disintegrate any remaining clumps. Particle separation was further promoted by ultrasonication $(10 \mathrm{~min})$ in $20 \mathrm{ml}$ scintillation bottles prior tu the experiments. Stock solutions (ca $1.6 \times 10^{9}$ particles $\mathrm{l}^{-1}$ ) were kept refrigerated between experiments, and a new solution was prepared whenever any bacterial contamination was detected (usually after 1 to $2 \mathrm{wk}$ ). The total particle concentration of the different stock solutions was found to vary slightly in spite of the similar preparation procedure. Hence, the concentration of every new solution was checked by counting at least 3 replicate $2.5 \mathrm{ml}$ subsamples with a Leitz Labovert inverted microscope, and the volume of the final additions was adjusted accordingly. The size distribution of the particles did not seem to be prone to significant variations between different stock solutions (Fig. 1).

The experiments in 1989 were made in 3 acidwashed 9 l transparent polycarbonate bottles. The experimental procedure for 1987 was otherwise similar, but for 2 replicate bottles being incubated at $1 \mathrm{~m}$ depth. Water from just below the surface, and from 5 and $10 \mathrm{~m}$ depths was collected with a tube sampler, and 81 was gently poured into each bottle. The starch particle additions in 1989 were adjusted to give a final concentration of $1.0 \times 10^{6}$ particles $1^{-1}$ in the bottles; in 1987 , the addition level was higher $\left(8.1 \times 10^{6}\right.$ particles $1^{-1}$ ). After adding the starch solution and mixing, by gently turning the bottles upside down several times, the bottles were lowered to their original sampling depths for in situ incubation. The rig to which the bottles were attached was constructed so as to transmit the surface wave action down to all bottles, in order to keep the particles in suspension. Sampling occurred at 5, 15 and 30 min after the additions (in 1987, the time series was $5,10,20$ and $30 \mathrm{~min}$ ). Samples of 0.51 were drawn from the bottles and preserved immediately with acid Lugol's iodine solution. An addition of $300 \mu l$ of standard acid Lugol's solution per 0.5 l sample generally produced satisfactorily stained specimens.

In the laboratory, the samples were settled in 50 or $100 \mathrm{ml}$ tubes according to the Utermöhl (1958) method.

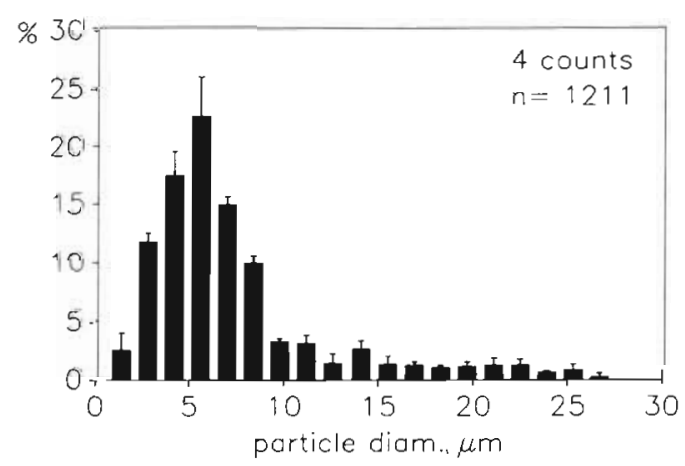

Fig. 1 Size distribution of wheat starch particles in the solution used for the grazing experiments 
The samples were examined with a Leitz Labovert microscope using phase contrast under $125 \times, 310 \times$ and $500 \times$ magnifications. Phase contrast was used for locating ciliates and for superficial examination of the particles ingested. However, bright field was needed to discriminate between starch particles and material of algal origin in the ciliate cell (see 'Discussion'). The ciliates were identified, the particles inside the cells were counted, and the diameter (or greatest length, if not spherical) of every ingested particle was measured. Sizing of the particles was done using an ocular micrometer under $500 \times$ magnification. This procedure resulted in size class categorization of the particles, starting at $1.4 \mu \mathrm{m}$ and increasing with an increment of $1.4 \mu \mathrm{m}$. Moving averages of the successive size classes were used in the calculations. This was found to be necessary as we later noticed that both counters more often categorized the particles in the 'whole' size classes (i.e. 1, 2, 3, etc. steps on the micrometer) than in the 'half' $(0.5,1.5,2.5$, etc. $)$ size classes.

Particle size selectivity of the ciliates was studied using the $\chi^{2}$-based ' $V$-index' $(V)$ (according to Pearre 1982):

$$
V= \pm\left(\frac{\chi^{2}}{\mathrm{n}}\right)^{1 / 2}
$$

The $\chi^{2}$ value was calculated using the percentages of particles ingested and offered in each size class; $n$ is the total number of particles ingested. The index may attain values from -1 to 1 (although extreme values are very rare). Positive values indicate selection for a certain particle size class and negative values selection against it.

When calculating the selectivity indices, the abilities of different ciliates to utilize particles of different size ranges had to be taken into account. While every ciliate was offered the same particle spectrum 11.4 to $40 \mu \mathrm{m}$ ), most of them used only a narrow slice of the spectrum. For example, Strombidium sp. $20 \mu \mathrm{m}$ (in size) ingested particles only in the 4 smallest size classes. To calculate the selectivity indices for these size classes, we had to leave the rest of the offered particles out, and re-scale the relative proportions of these 4 size classes to make the percentages add up to $100 \%$. Thus, most ciliates have a different relative proportion of a certain size class in their offered food spectrum.

Clearance rates $(C)$ were calculated as:

$$
C=\frac{I}{P}
$$

where $P$ is the starch particle concentration (particles $\mathrm{Hl}^{-1}$ ) in the experimental units and $I$ is the particle ingestion rate (particles cell ${ }^{-1} \mathrm{~h}^{-1}$ ).

I was calculated as:

$$
I=\frac{p}{C} \times \frac{1}{T_{\mathrm{h}}}
$$

where $p$ is the total number of particles found in all cells of a ciliate species in 1 sample, $c$ is the total number of the cells of a species in the sample, and $T_{\mathrm{h}}$ is time in hours. We used, with the exception of the 1987 experiment, a time of $5 \mathrm{~min}(0.083 \mathrm{~h})$.

The total particle concentration used in the 1989 experiments was chosen after preliminary uptake experiments with different concentrations $\left(10^{4}\right.$ to $10^{8}$ particles $1^{-1}$ ). As a result, the concentration was adjusted to $10^{6}$ added particles $1^{-1}$. Another reason for this decision was the 1.1 to $1.8 \times 10^{7} 1^{-1}$ density range of nanoflagellates (P. Kuuppo-Leinikki, Academy of Finland, pers. comm.) during June and July, the supposedly primary prey of the ciliates studied. Consequently, the $10^{6}$ addition kept the offered food (consisting mainly of nano-sized particles) concentration below $10 \%$ of the natural food concentrations. The higher concentration used in the 1987 experiment may have pushed the limits of the tracer criteria.

The 1987 experiment was done in June, during daytime, with a water temperature of $14^{\circ} \mathrm{C}$. The 1989 experiments were run in June and July, when the water column was stratified, which is typical for the summer period, with a thermocline at 8 to $12 \mathrm{~m}$ depth. Days and nights with low wind velocities $\left(<5 \mathrm{~m} \mathrm{~s}^{-1}\right)$ were chosen for the experiments. Water temperature ranged from 10.0 to $16.7^{\circ} \mathrm{C}$. The highest values were found at the surface, while the thermocline region (approximately corresponding to the incubations at $10 \mathrm{~m}$ depth) was usually cooler, with the exception of the 11 July 1989, when temperature in the upper $10 \mathrm{~m}$ layer was uniform $\left(16.7^{\circ} \mathrm{C}\right)$. The $10 \mathrm{~m}$ surface layer corresponded well with the euphotic layer, as the $1 \%$ PAR level was always found at 9 to $10 \mathrm{~m}$ depth. No salinity measurements were made in this study, but the typical values for the area and season of the $10 \mathrm{~m}$ surface layer are around 5.5 to $6 \%$. For detailed information on the hydrography of the study area, see Niemi (1975).

The nomenclature of the naked ciliates in this study is based on the work of Lynn \& Montagnes (1988). The most notable difference with former studies (e.g. Jonsson 1986) is that the genus Lohmanniella now has only 1 Baltic representative ( $L$. oviformis), and the former L. spiralis is presently named Strobilidium spiralis. Tintinnid names follow the lines of Bakker \& Pfaff (1976).

\section{RESULTS}

\section{Time series of particle uptake}

On the first 2 sampling occasions ( 5 and $15 \mathrm{~min}$ ) in the 1989 experiments, the majority of ciliates did not contain any particles. However, as a large number of 
Table 1. Species-specific clearance rates of ciliates $\left(\mu l\right.$ cell $\left.{ }^{-1} h^{-1}\right) \cdot n_{c e l l}$ and $n_{\text {part }}$ numbers of cells and ingested particles used in the clearance rate calculations; $C_{t}$ : average clearance rate on the whole species-specific particle spectrum in all experiments; $C_{p}$ : average clearance rate on the most popular particle size; SD: standard deviation between experiments; Min and Max: corresponding minimum and maximum clearance rates observed. Clearance rates of the non-tintinnid ciliates were calculated after 5 min incubation; clearance rates of the tintinnids are averages of the results of 5 and 10 min incubations. Note that the higher particle concentrations used with the tintinnid experiment elevated the $\mathrm{n}_{\text {part }} / \mathrm{n}_{\text {cell }}$ ratio

\begin{tabular}{|c|c|c|c|c|c|c|c|c|c|c|}
\hline Species & $\mathrm{n}_{\text {cell }}$ & $\mathrm{n}_{\text {part }}$ & $C_{\mathrm{t}}$ & $\mathrm{SD}$ & Min & $\operatorname{Max}$ & $C_{\mathrm{p}}$ & $\mathrm{SD}$ & Min & $\operatorname{Max}$ \\
\hline Lohmanniella oviformis & 521 & 112 & 3.3 & 2.7 & 1.1 & 8.4 & 5.3 & 3.3 & 2.2 & 10.6 \\
\hline Strobilidium sp. $40 \mu \mathrm{m}$ & 455 & 128 & 4.6 & 1.2 & 2.5 & 5.8 & 10.1 & 6.1 & 2.5 & 17.3 \\
\hline Strobilidium spiralis & 274 & 91 & 6.6 & 2.7 & 4.0 & 10.1 & 11.4 & 3.9 & 6.1 & 15.3 \\
\hline Strombidium sp. $20 \mu \mathrm{m}$ & 308 & 49 & 3.9 & & & & 7.5 & & & \\
\hline Strombidium spp. $25 \mu \mathrm{m}$ & 892 & 212 & 3.1 & 1.1 & 1.7 & 4.6 & 5.5 & 2.0 & 4.1 & 9.0 \\
\hline Strombidium conicum & 103 & 26 & 3.7 & 1.3 & 2.8 & 4.7 & 8.1 & 3.7 & 5.5 & 10.7 \\
\hline Tintinnidium fluviatile & 35 & 87 & 1.1 & & & & 1.9 & & & \\
\hline Tintinnopsis beroidea & 30 & 63 & 1.9 & & & & 8.4 & & & \\
\hline Tintinnopsis lobiancoi & 23 & 86 & 4.8 & & & & 5.8 & & & \\
\hline
\end{tabular}
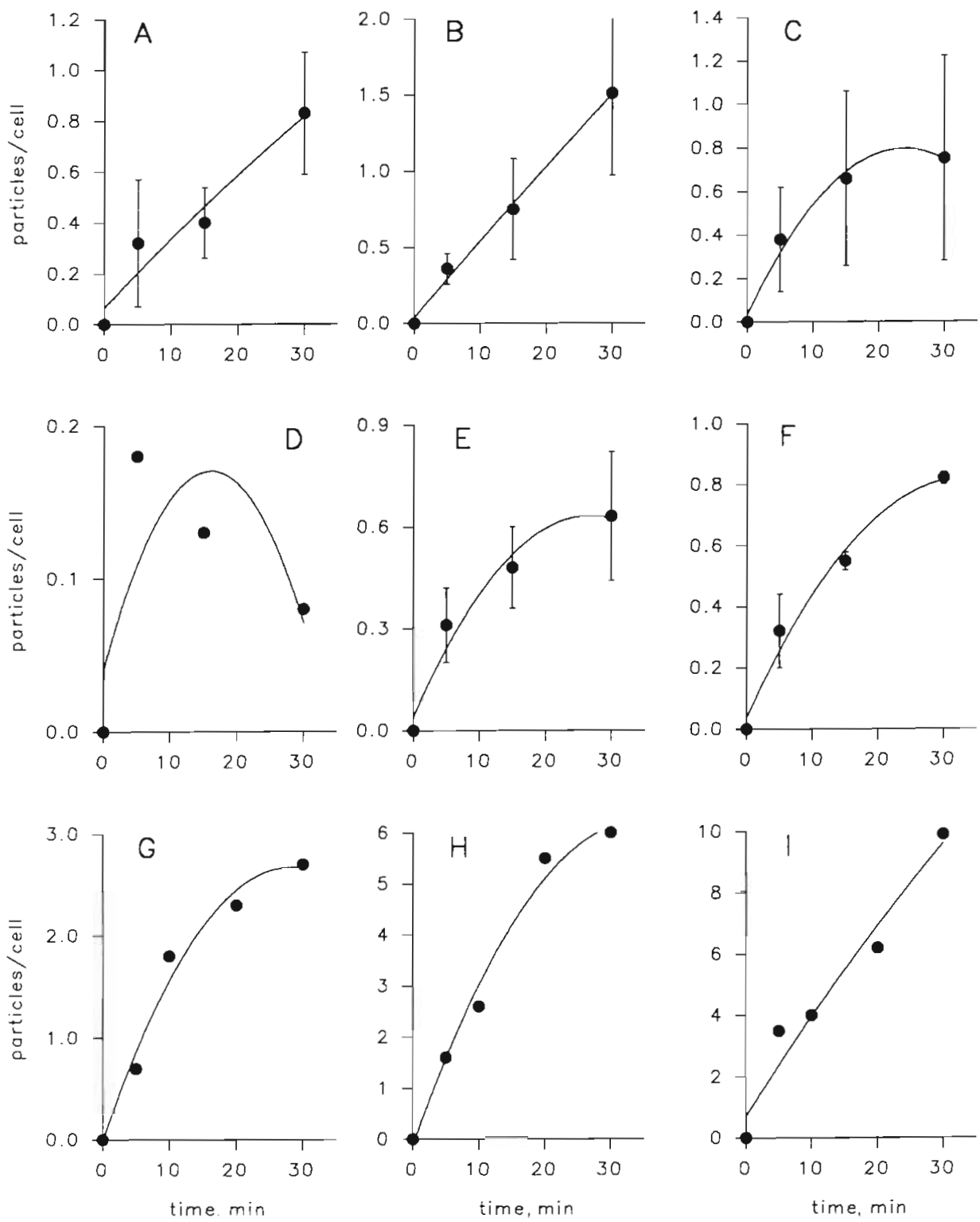

Fig. 2. Particle accumulation in the ciliates as a function of the duration of the experiment. (A) Lohmanniella oviformis; (B) Strobilidium sp $40 \mu \mathrm{m}$; (C) Strobilidium spiralis; (D) Strombidium $\mathrm{sp}$ $20 \mu \mathrm{m}$; (E) Strombidium spp. $25 \mu \mathrm{m}_{i}$ (F) Strombidium conicum; (G) Tintinnidium fluviatile; $(\mathrm{H})$ Tintinnopsis beroidea: (I) Tintinnopsis lobiancoi. Note that the higher numbers of particles in the tintinnid cells $[(G)$ to (I)] reflect the higher concentration of particles offered in the 1987 experiment. Second-order regression curves are fitted to the data 
ciliates were included in the experiments, a sufficient number had always ingested 1 or more particles to allow for clearance rate calculations (Table 1). For the selectivity calculations, we could use a larger quantity of the particles, because all the particles ingested during a time series were taken into account. This scheme was based on the assumption that the size selectivity of the ciliates does not change during the 30 min experiment. One consequence of the low particle concentration was usually a low number of particles in the cells. This proved to facilitate counting and particle size measurements. The 1987 experiment with the tintinnids was an exception, where the offered particle concentration as well as the particle numbers observed in the cells were higher.

Time series of particle ingestion of the ciliates are presented in Fig. 2. The second-order regressions fitted to the data show that the slopes of the curves are usually steepest during the first $5 \mathrm{~min}$. They become more gentle between 5 and $15 \mathrm{~min}$, and finally level out when reaching $30 \mathrm{~min}$. The flattening of the curves seems to be a consequence of the ciliate populations reaching an equilibrium between particle uptake and digestion (or egestion) somewhere close to $30 \mathrm{~min}$. There are, however, notable exceptions: particle accumulation in the cells of Lohmanniella oviformis, Strobilidium sp. $40 \mu \mathrm{m}$ and Tintinnopsis lobiancoi appear to be linear during the first $30 \mathrm{~min}$. However, the linearity can not be expected to continue indefinitely. On the other hand, the small Strombidium sp. $20 \mu \mathrm{m}$ seems to attain a particle equilibrium very quickly, i.e. during the first 5 min. Theoretically, in the 1989 experiments, ca 10 to $40 \%$ of the cells contained 1 particle after the first $5 \mathrm{~min}$. In reality these percentaces are too high; although there were cells with several ingested particles, the majority of the ciliates had not ingested any particles.

Most species showed the highest average ingestion rates after $5 \mathrm{~min}$; consequently we selected this point of the time series for obtaining the maximum clearance rates. The average clearance rates at 15 and $30 \mathrm{~min}$ were always clearly lower than those at $5 \mathrm{~min}$. Again, an exception was made with the tintinnids, as their clearance rates are the result of averaging the 5 and 10 min values, due to the small number of cells in each sample.

\section{Clearance rates}

Two different clearance rate values were computed for each species. These values were calculated from the particle ingestion rates averaged over the 3 depths and all different experiments (1989; the 1987 values are averages of 2 replicates). The results, with stan- dard deviations between experiments, and minimum and maximum clearance rates observed (when applicable), are presented in Table 1. First, we calculated the 'overall' species-specific clearance rates by using the total number of particles ingested. In the second method we used the concentration of the most popular species-specific particle size class, revealed by the selectivity index calculations. The clearance rates obtained with the former method were in most cases substantially lower ( 23 to $83 \%$ ) than with the latter.

Biomass-specific clearance rates of the ciliates are presented in Fig. 3. There was a statistically significant correlation $(p<0.01)$ between the ciliate biomass and the clearance rate on the whole particle range of a species, but not between biomass and clearance rate on the most popular particle size.

The dependence of ciliate clearance rates on water temperature, and the possible differences between night and day clearance rates, were studied by plotting the rates from 4 experiments ( 2 consecutive night/day experiments) against temperature at the 0,5 and $10 \mathrm{~m}$ incubation depths (Fig. 4). Data are only shown for the 4 species present in sufficiently high densities in these diel experiments. The results suggest that temperature has different effects on the clearance capabilities of the different species. Strombidium spp. $25 \mu \mathrm{m}$ and Strobilidium spiralis had lower clearance rates in warm water (Fig. 4A, B), whereas Strobilidium sp. $40 \mu \mathrm{m}$ and Lohmanniella oviformis tended to have higher clearance rates in the warm surface water (Fig. 4C, D). No clear disparity was detected between night and day clearance rates for the species studied that could not be explained by differences in temperature.

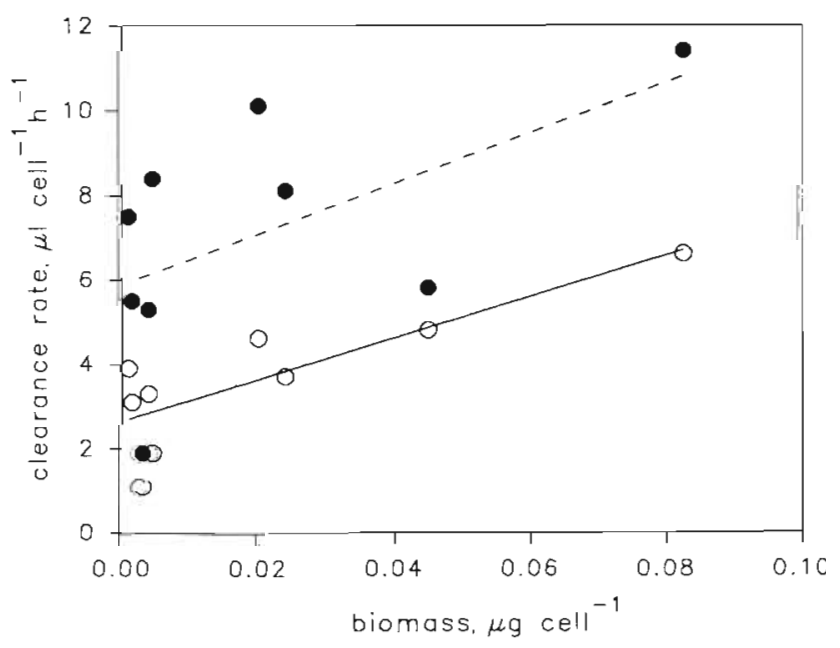

Fig. 3. Ciliate clearance rates versus cell biovolumes. (o) Clearance rates obtained using the total number of particles ingested $\left(C_{1}\right)_{i}(\bullet)$ clearance rates obtained using the number of most popular particle ingested $\left(C_{p}\right)$. Correlation between biovolume and $C_{2}: r=0.828, p<0.01, y=2.67+47.57 x$ 

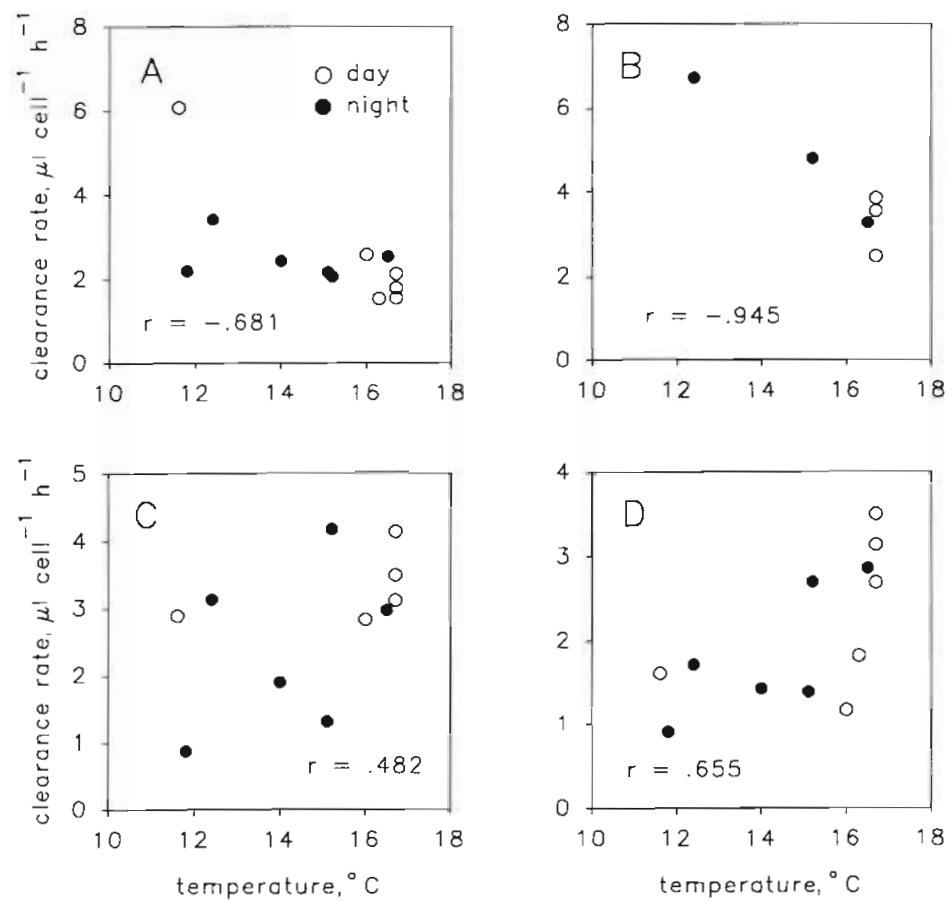

Fig. 4. Ciliate clearance rates versus temperature (from incubations at different depths). The clearance rates are only from 4 experiments, and thus do not correspond with the values in Table 1. (A) Strombidium spp. $25 \mu \mathrm{m}$; (B) Strobilidium spiralis; (C) Strobilidium sp. $40 \mu \mathrm{m}_{\text {; }}$ (D) Lohmanniella oviformis. (O) Daytime values; $(\bullet)$ night-time values. For $(A)$ and (D), $p<0.05$; for $(B), p<0.01$

\section{Particle size selectivity}

The size range of particles ingested by each ciliate species varied greatly (Table 2 ). Generally, small ciliates readily ingested small particles and showed a narrower particle range; larger ciliates usually had wider particle ranges and preferred larger granules. The ciliates we studied represent 3 different oligotrich types. The tintinnids Tintinnidium fluviatile, Tintinnopsis beroidea and Tintinnopsis lobiancoi are loricated ciliates, while the Strombidium spp. have a poly-

Table 2. Ingested particle size ranges $(R)$ for different ciliate species and the most popular particle sizes ( $P$; second choice in parentheses)

\begin{tabular}{|c|c|c|}
\hline Species & $R(\mu \mathrm{m})$ & $P(\mu \mathrm{m})$ \\
\hline Lohmanniella oviformis & $1.4-11.2$ & $5.6(4.2)$ \\
\hline Strobilidium sp. $40 \mu \mathrm{m}$ & $1.4-26.6$ & $9.8(15.4 ; 12.6)$ \\
\hline Strobilidium spiralis & $1.4-16.8$ & $5.6(8.4)$ \\
\hline Strombidium sp. $20 \mu \mathrm{m}$ & $1.4-5.6$ & $2.8(1.4)$ \\
\hline Strombidium spp. $25 \mu \mathrm{m}$ & $1.4-9.8$ & $5.6(4.2)$ \\
\hline Strombidium conicum & $2.8-25.2$ & $4.2(5.6)$ \\
\hline Tintinnidium fluviatile & $1.4-8.4$ & $4.2(2.8)$ \\
\hline Tintinnopsis beroidea & $1.4-8.4$ & $4.2(2.8)$ \\
\hline Tintinnopsis lobiancoi & $2.8-23.8$ & $5.6(4.2)$ \\
\hline
\end{tabular}

saccharide cone in the posterior part of the cell, and Lohmanniella oviformis and the Strobilidium spp. are naked oligotrichs. In all these groups various preferences for particle sizes were observed. Among the tintinnids (Fig. 5), the small $T$. fluviatile and $T$. beroidea ingested small particles, showing preferences for granules of 2.8 and $4.2 \mu \mathrm{m}$ in size, while the larger $T$. lobiancoi proved to ingest a wide range of particles without having a very clear preference for any distinct size class.

The Strombidium sp. $(20 \mu \mathrm{m})$ preferred the smallest particles (1.4 and $2.8 \mu \mathrm{m})$, and strongly selected against larger granules, having also the narrowest particle range (Fig. 6). The little larger Strombidium spp. (25 $\mu \mathrm{m})$ preferred particles from $2.8 \mu \mathrm{m}$ to $5.6 \mu \mathrm{m}$, and clearly selected against other particle sizes. The largest species of the group, S. conicum, showed a selectivity pattern rather similar to that of Tintinnopsis lobiancoi, but it also ingested particles up to $25 \mu \mathrm{m}$ in size.

The small (25 $\mu \mathrm{m}$ ) Lohmanniella oviformis selected granules in the 2.8 to $5.6 \mu \mathrm{m}$ range, its upper particle size limit being in the $11.2 \mu \mathrm{m}$ size class (Fig. 7). Strobilidium spiralis (average cell size 50 to $60 \mu \mathrm{m}$ ) showed the most clear-cut particle preference of all the species studied, revealing a high selection for the $5.6 \mu \mathrm{m}$ size class and a selection against all other except the $8.4 \mu \mathrm{m}$ size class. The medium-sized $(40 \mu \mathrm{m})$ Strobilidium $\mathrm{sp}$. had a peculiar selectivity pattern and a very wide size range of ingested particles (Fig. 7). This species showed a preference for particles from $4.2 \mu \mathrm{m}$ up to $19.6 \mu \mathrm{m}$ in size (with the exception of low selection against the $5.6 \mu \mathrm{m}$ size class), and it clearly selected against only the 2 smallest particle sizes. This species had frequently ingested 1 to 3 very large granules filling almost the entire cell.

\section{DISCUSSION}

\section{Clearance rates of the ciliates}

The ciliate clearance rates obtained in this study agree well with most observations from other aquatic environments (see references in Table 3, where clearance rates for oligotrich ciliates from other studies are presented, along with some of our results for comparison).

In spite of the general agreement of the values in Table 3 , there are some noteworthy differences. The 
Fig. 5. Particle ingestion and selectivity index $V$ of the tintinnids. Left column: Percentages of particles offered (adjusted to the range of ingested particles) indicated by the solid line; percentages of particles ingested indicated by the bars. $n$ : total number of cells in the samples; np: total number of ingested particles counted. Right column: $V$ selectivity index of the ciliates on different particle size classes. SD bars (between experiments) are given only for the species present in a sufficient number of experiments
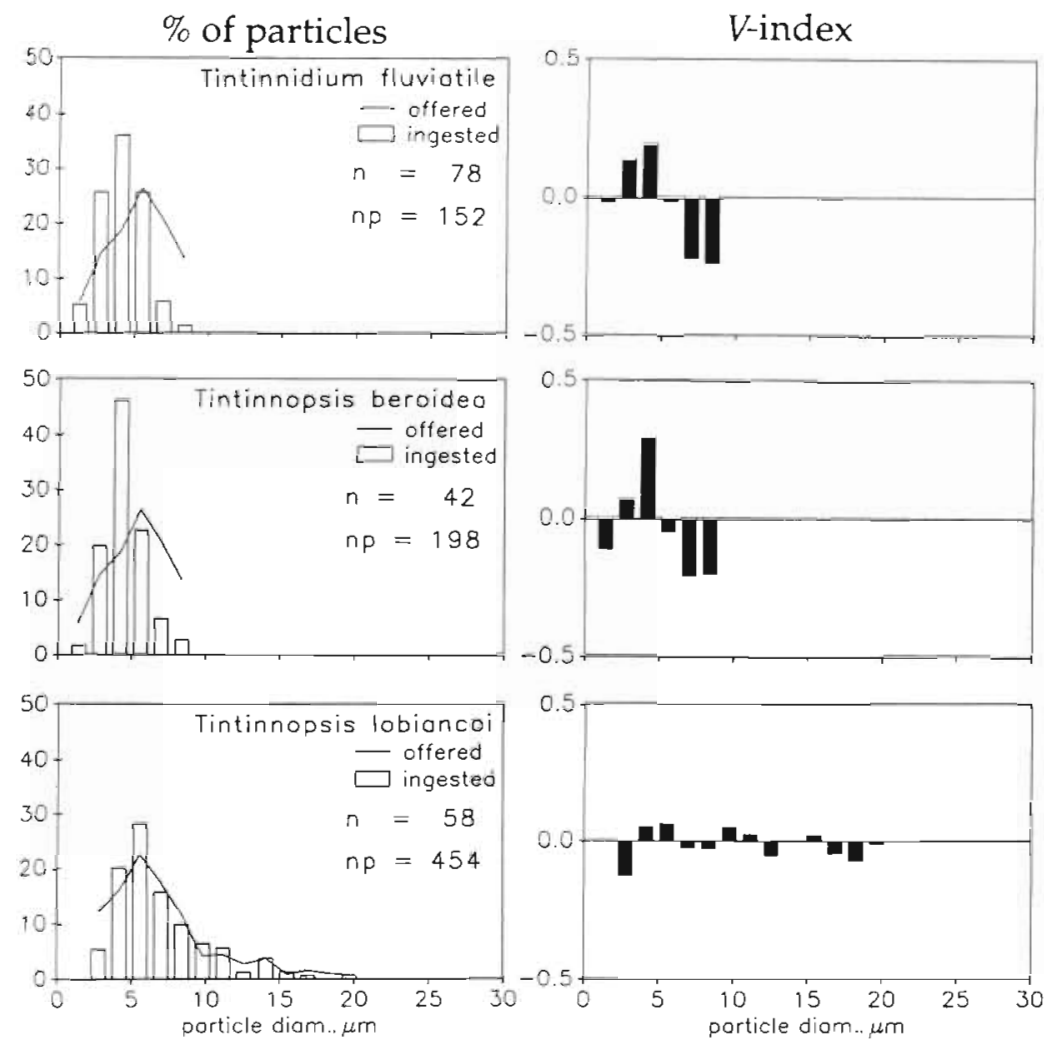

$\%$ of particles

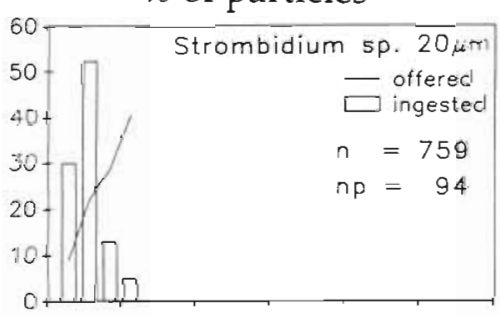

$V$-index
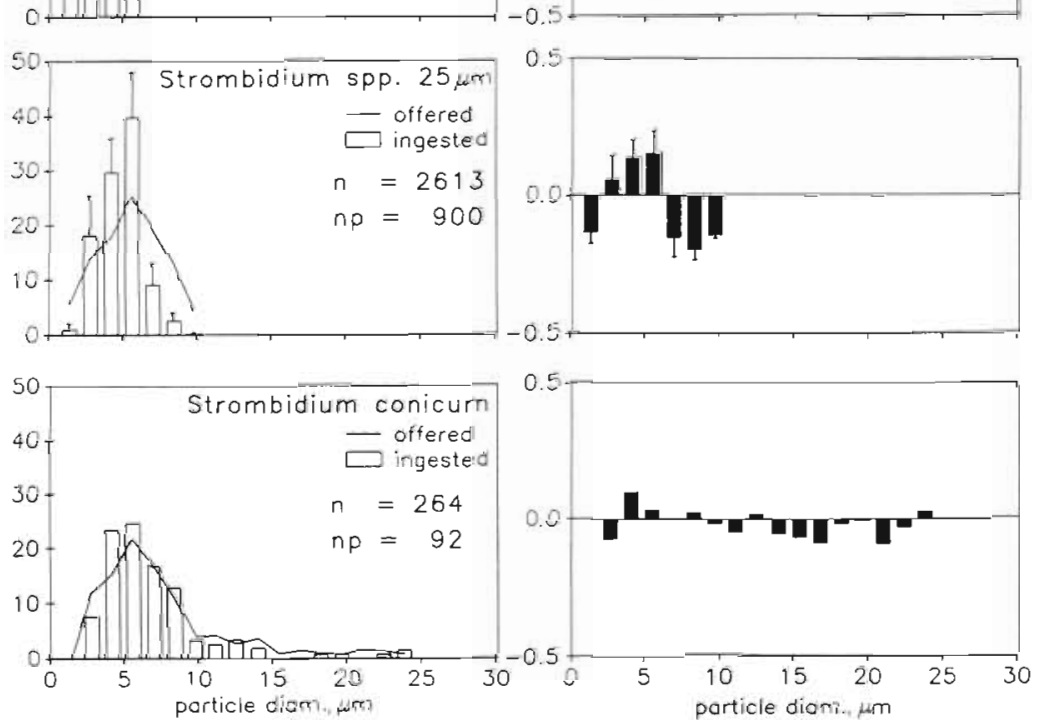

Fig. 6. Particle ingestion and selectivity index $V$ of the strombidids. Symbols as in Fig. 5 
$\%$ of particles
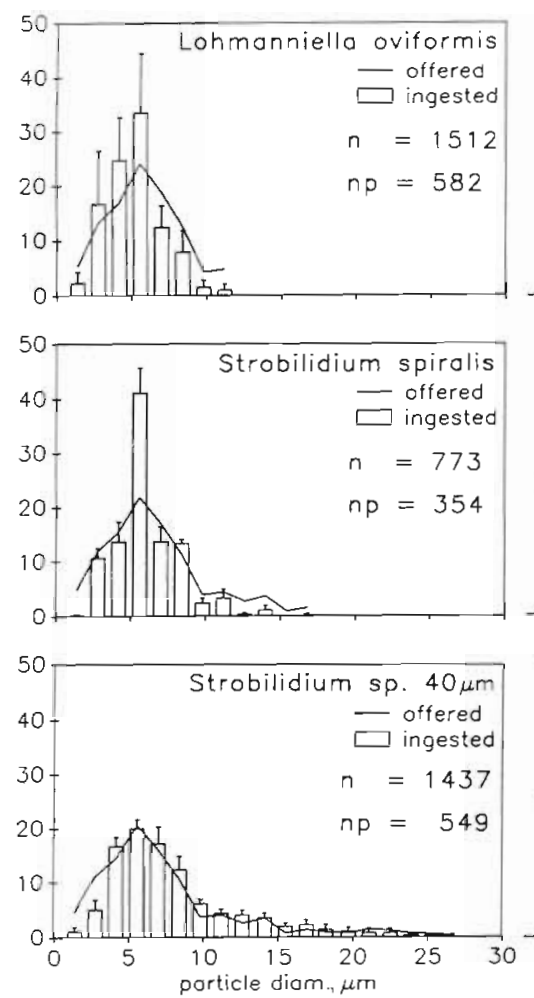

$V$-index
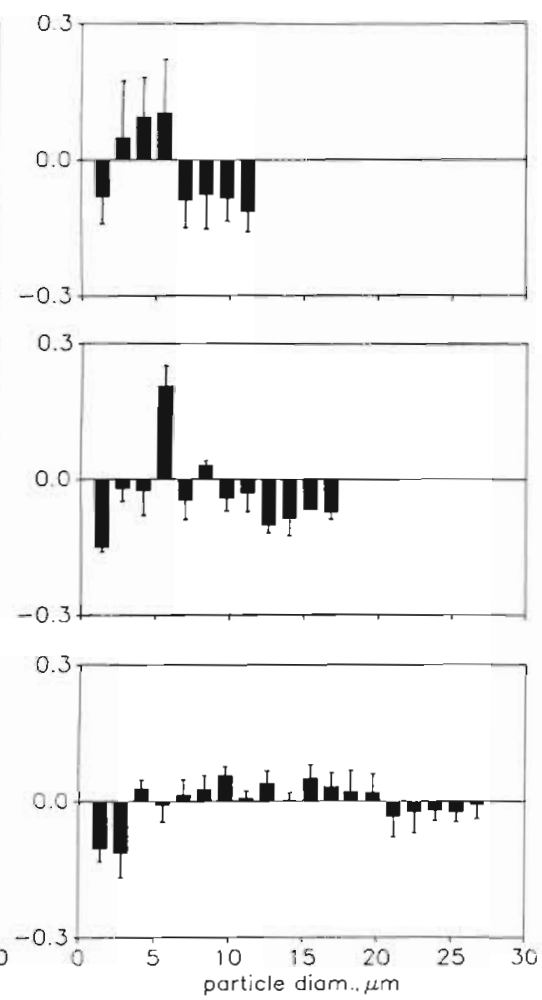

Fig 7. Particle ingestion and selectivity index $V$ of the strobilidids. Symbols as in Fig. 5 clearance rates of the small strombidids in our study are somewhat higher than those obtained previously. This difference is mainly caused by the 'most popular particle' method (i.e. the maximum rates) used in our calculations. This result indicates that also small, specialized ciliates can have relatively high clearance rates on certain particle sizes, even if their overall clearance rates remain low. However, even the 'overall' clearance rate of Strombidium sp. $20 \mu \mathrm{m}$ is, according to our results, clearly higher than those of Scott (1985) or Jonsson (1986), obtained with Strombidium spp. of similar size. The high clearance rate in Lessard \& Swift (1985) for 1 unidentified Strombidium species may be explained by the method they used $\left({ }^{14} \mathrm{C}\right.$ labelled food, ingestion measured as uptake of the isotope). Some Strombidium species are famous for retaining chloroplasts with photosynthetic capacity in their cells (Stoecker et al. 1987, Laval-Peuto \& Rassoulzadegan 1988). It is possible that uptake of ${ }^{14} \mathrm{C}$ (due to the continuing activity of ingested chloroplasts) took place during the incubations, thereby appearing as an anomalously high clearance rate. The photosynthetic abilities of some ciliates clearly pose a problem in experiments where ${ }^{14} \mathrm{C}$-labelled food organisms are used, and the radioactivity of the grazers is then interpreted as an indication of their grazing rates.
The method used in our study did not allow direct measurements of bacteria-size particle uptake. However, the selectivity patterns of Strombidium sp. $20 \mu \mathrm{m}$ and Tintinnidium fluviatile gave indications that these species may be able to graze on sub-micrometer particles. Small ciliates have been observed to graze effectively on bacteria (e.g. Albright et al. 1987), the clearance rates being usually $\leq 1 \mu \mathrm{l} \mathrm{cell}{ }^{-1} \mathrm{~h}^{-1}$ (Børsheim 1984: 0.23 to $1.26 \mu \mathrm{l} \mathrm{cell}^{-1} \mathrm{~h}^{-1}$; Sherr \& Sherr 1987: 0.14 to $\left.0.27 \mu \mathrm{lcell}^{-1} \mathrm{~h}^{-1}\right)$. This phenomenon may also be due to facultative ingestion of bacteria.

Our clearance rate results are in the same range as those obtained for some microplanktonic organisms other than ciliates. If heterotrophic nanoflagellates had body volumes comparable to those of ciliates, they would ingest bacteria as effectively as ciliates do (Rivier et al. 1985). Lessard \& Swift (1985) give clearance rates of up to $28.3 \mu \mathrm{l} \mathrm{cell-1} \mathrm{h}^{-1}$ for heterotrophic dinoflagellates (including the common Baltic genus Protoperidinium). Also some freshwater planktonic rotifers (Kellicottia, Brachionus) have clearance rates comparable to those of planktonic ciliates $(<10 \mu \mathrm{l}$ ind. ${ }^{-1} \mathrm{~h}^{-1}$; Bogdan et al. 1980). Clearance rates of similar magnitudes have been estimated even for calanoid copepods: the ranges of some measurements reach from 0.4 to $300 \mu \mathrm{l}$ ind. ${ }^{-1} \mathrm{~h}^{-1}$, typical values being 
Table 3. Ciliate clearance rates $\left(\mu l\right.$ cell $\left.^{-1} h^{-1}\right)$ found in literature, compared with our rates. In Jonsson's (1986) study the values in parenthesis are results with live food; the other values are from feeding on latex beads

\begin{tabular}{|lcl|}
\hline Organism & Clearance rate & Source \\
\hline Tintinnids (mainly) & $1.0-84.7$ & Capriulo \& Carpenter (1980) \\
Tintinnids & $1.6-32.0$ & Lessard \& Swift (1985) \\
Tintinnopsis acuminata & $1.0-3.5$ & Heinbokel (1978a) \\
Helicostomella subulata & $0.5-4.8$ & Heinbokel (1978a) \\
Helicostomella subulata & 2 & Andersen \& Sorensen (1986) \\
Favella taraikaensis & $0.4-14.5$ & Taniguchi \& Kawakami (1985) \\
Stenosemella ventricosa & up to 18 & Rassoulzadegan \& Etienne (1981) \\
Tintinnids & $1.9-8.4^{\mathrm{a}}$ & This study \\
Strobilidium spiralis & 43.0 & Lessard \& Swift (1985) \\
Strobilidium spiralis & $11.0(9.9)$ & Jonsson (1986) \\
Strobilidium spiralis & $11.4^{\mathrm{a}}$ & This study \\
Strombidium reticulatum & $1.7(2.6)$ & Jonsson (1986) \\
Strombidium vestitum & $0.13(0.13)$ & Jonsson (1986) \\
Strombidium spp. & $0.8-8.6$ & Lessard \& Swift (1985) \\
Strombidium sp. & $213^{\mathrm{b}}$ & Lessard \& Swift (1985) \\
Strombidium spp. & $0.08-1.46$ & Scott (1985) \\
Strombidium spp. $25 \mu \mathrm{m}$ & $5.5^{\mathrm{a}}$ & This study \\
Strombidium sp. $20 \mu \mathrm{m}$ & $7.5^{\mathrm{a}}$ & This study \\
'The values of this study are those obtained with the 'most popular particle'-method \\
'See text for discussion of this very high value \\
\hline
\end{tabular}

around 10 to $50 \mu \mathrm{l}$ ind..$^{-1} \mathrm{~h}^{-1}$ (Berggreen et al. 1988, White \& Roman 1992).

Some attempts have been made to relate ciliate clearance rates to biovolume, in the hope of demonstrating a general dependence between these 2 factors. Bernard \& Rassoulzadegan (1990) established a strict correlation between the average as well as modal (the particle size grazed on most effectively) prey particle sizes on the biovolume of several Mediterranean planktonic ciliates. This, indeed, seems to be the case with the ciliates in our study, although the correlation is significant only if the clearance rates are based on the total number of particles ingested.

The ingestion rates of ciliates and many other planktonic organisms (e.g. Mullin et al. 1975) are strongly dependent on food particle concentration, and there are indications that ingestion rates follow either 'rectiLinear' (Frost 1975) or Michaelis-Menten type saturation kinetic models (e.g. Rublee \& Gallegos 1989). As clearance rate is a function of ingestion rates and food particle concentration (Eq. 2), it is a more conservative indicator of the feeding behaviour of an organism than ingestion rates. This follows from the uptake being practically linear (or being able to be treated as such) in a wide range of lower concentrations, no matter which model is used to describe ingestion rate as a function of food concentration. Thus, the clearance rates derived from ingestion rates remain constant up to the half-saturating concentration of MichaelisMenten type kinetics or to the discontinuity concentration of the rectilinear model.
In our work, a satisfactory study of uptake kinetics, with different particle concentrations was not done. However, we believe it safe to assume that if the total concentration of added particles is in the order of $10^{6} \mathrm{l}^{-1}$, the addition remains on a tracer level $(<10 \%$ of naturally occurring food items) during the summer months in the northern Baltic. If this assumption is valid, our measured clearance rates should represent the maximum rates of the ciliates. In oligotrophic seas, such as the northern Baltic, the planktonic organisms usually live in nutritionally dilute environments. For example, Fenchel (1980b) and Jonsson (1986) have shown that ciliate ingestion rates on $1.1 \mu \mathrm{m}$ and $5.7 \mu \mathrm{m}$ sized particles, as a function of particle concentration, become non-linear only at concentrations that are an order of magnitude, or 2, above the natural summer concentrations of bacteria and nanoflagellates in the northern Baltic (ca $10^{9}$ and $10^{7} 1^{-1}$, respectively). Thus, even the highest concentrations used in our experiments $\left(8.1 \times 10^{6} 1^{-1}\right.$, with the tintinnids) should be well within the range of constant clearance rates.

Ciliate clearance rates are apparently not dependent only on food particle concentration. The effects of temperature, food quality, and possible diurnal cycles on ciliate feeding remain inadequately studied subjects in protozoan ecology. In our data, the effect of temperature on clearance rates of different ciliates showed variable results (Fig. 4), and the only explanation seems to be that either the ciliates have adapted to different temperature optima, or there is some unknown factor causing the variation observed in the clearance 
rates. It also appears that no clear-cut diurnal differences, such as those exhibited by calanoid copepods, could be shown to exist in ciliate feeding. Considering all the factors (food concentration, temperature, etc.) known to possibly affect the clearance rates of planktonic ciliates, it seems probable that the natural ciliate populations in the northern Baltic pelagial are practically always, in the framework of their temperaturelimited metabolism, exercising clearance at their maximum possible rates.

\section{Particle selectivity}

Today it is widely recognized that planktonic ciliates feed mainly on pico- and nano-sized organic particles, including bacteria (Rivier et al 1985, Sherr \& Sherr 1987), coccoid cyanobacteria (Rassoulzadegan et al. 1988, Rublee \& Gallegos 1989), auto- and heterotrophic nanoflagellates and small dinoflagellates (Smetacek 1984). Especially holotrichs and hymenostomes (Fenchel 1980a, b, Turley et al. 1986), as well as small oligotrichs and spirotrichs (Gast 1985), seem to be able to extend their prey size range down to bacteria, but observations on some peritrichs also suggest that they tend to utilize the lower end of the size range of the prey items available (Børsheim 1984, Kuosa 1990). On the other hand, some oligotrichs, like Strobilidium spiralis (Smetacek 1984) and the Strobilidium sp. $40 \mu \mathrm{m}$ in this study, can utilize food items almost as large as themselves. As a whole, the planktonic microprotozoan community seems to be, at almost any time of the year, adapted to utilizing a wide range of food organisms and to competing with metazoans for food (Kivi et al. 1993)

Heinbokel (1978a) set the general rule that tintinnids are able to ingest food particles with a diameter of up to $43 \%$ of their own lorica opening. According to his results, they use particles from ca 4 to $25 \mu \mathrm{m}$ in diameter. In our study, all tintinnids also ingested smaller particles, the lower limit being 1.4 to $2.8 \mu \mathrm{m}$; Heinbokel's upper limit seems to agree well with our results. There is evidence that tintinnids graze effectively only on a part of their potential prey size range. Rassoulzadegan \& Etienne (1981) found Stenosemella ventricosa to concentrate on 3 to $12 \mu \mathrm{m}$ particles. Of the 3 tintinnids in this study only Tintinnopsis lobiancoi ingested a wide range of particles (2.8 to $23.8 \mu \mathrm{m})$ with approximately similar effectivity for every size class.

There is plenty of evidence that aloricate oligotrichs utilize mainly food particles less than $10 \mu \mathrm{m}$ in diameter. Jonsson (1986) found the most popular particle size for Strobilidium spiralis to be $9.7 \mu \mathrm{m}$, for Strombidium reticulatum $7.9 \mu \mathrm{m}$, and for Strombidium vestitum $2.1 \mu \mathrm{m}$. Bernard \& Rassoulzadegan (1990) observed
Strombidium sulcatum feeding only on particles $\leq 6.6 \mu \mathrm{m}$. Kuosa (1990) showed that the planktonic peritrich Cothurnia maritima had ingested large numbers of $2 \mu \mathrm{m}$ Synechococcus cells; also Strobilidium cf humile showed similar feeding preferences. In his study, S. spiralis cells contained primarily 6 to $8 \mu \mathrm{m}$ Cryptomonas cells, and 2 Strombidium spp. had ingested either 3 to $5 \mu \mathrm{m}$ or 6 to $8 \mu \mathrm{m}$ Cryptomonas cells It seems that when approaching the lower limit of their possible food particle range, ciliates tend to utilize the larger particles first ( $>1 \mu \mathrm{m})$, and then turn to graze on the smaller ones (<1 $\mu \mathrm{m}$; Turley et al. 1986).

Most of the ciliates in our study did not appear to excercise effective grazing on the smallest particles (Figs. 5 to 7). Two species, Tintinnopsis lobiancoi and Strobilidium sp. $40 \mu \mathrm{m}$, did not ingest any particles of the $1.4 \mu \mathrm{m}$ size class. Tintinnidium fluviatile ingested these particles with neutral selectivity and, in fact, only Strombidium sp. $20 \mu \mathrm{m}$ showed selection for this size class. In the light of previous studies, from other parts of the world (Lessard \& Swift 1985, Turley et al. 1986, Sherr et al. 1989), it could be expected that ciliates with the ability to utilize bacterial food also exist in the northern Baltic Sea.

One result of this study was the apparent presence of at least 2 kinds of feeding strategies among Baltic oligotrich ciliates. Of the 9 species studied, 6 showed preference for a narrow range of food particles ( 2 to 3 size classes). These ciliates seem to have specialized on the utilization of particles of certain sizes, and 1 species, Strobilidium spiralis, showed high preference for only $5.6 \mu \mathrm{m}$ particles. The remaining 3 species (Tintinnopsis lobiancoi, Strombidium conicum and Strobilidium $\mathrm{sp}$. $40 \mu \mathrm{m}$ ), each a representative of 1 main group, showed selectivity patterns quite different from that of the 'specialists'. These 'generalists' were characterized by a wide food spectrum and selectivity indices close to zero for most of the particle range.

\section{Starch particles in ciliate grazing studies}

The use of starch particles in ciliate grazing studies opens several possibilities, but also demands careful consideration of specific methodological elements. Preservation of the ciliates by acid Lugol's solution is necessary for staining the starch particles and making them clearly visible. Finding the right concentration for the preservative addition is a trade-off between good cell fixation and visibility of the particles. Moreover, many ciliates have starch-containing material (flagellate cells and chloroplasts) in their food vacuoles or elsewhere in the cell (chloroplasts retained for additional nutriment provision; e.g. Stoecker et al. 1988). The balance between proper particle staining and the 
possibility of mistaking bodies of algal origin for the added particles was delicate; we overcame the problem by using a low-acid Lugol concentration $10.06 \%$ final concentration), which stained the pure starch granules a deep violet, but usually left the starchcontaining algal bodies considerably less stained. In distinguishing between the naturally occurring and added starch particles inside the ciliate cells, we also used bright field illumination of high intensity and an open aperture. When examined this way, the natural particles usually became transparent, or appeared unevenly shaped and stained, whereas the added starch particles were more or less opaque and evenly stained.

The visibility of the smallest starch particles inside the cells was not always satisfactory. This applied mainly to the $1.4 \mathrm{~m}$ size class, which is clearly close to the detection limit of phase contrast or bright field light microscopy. In addition to the visibility problem, the smallest particles tended to be more irregularly shaped than the larger ones, which further complicated their identification. However, when in doubt, we preferred to reject rather than accept the particle in question; hence, our estimates concerning the smallest particle size class are probably biased towards lower selectivity values.

The use of various artificial particles as substitutes for natural food in grazing experiments may cause problems due to the chemosensory responses of the animals, as demonstrated by Verity (1988) with ciliates, and also by DeMott (1986) with rotifers and crustaceans. The fluorescent latex beads frequently used in flagellate and ciliate grazing experiments, as a substitute for bacterial prey, are ingested at significantly lower rates than fluorescently labelled natural bacteria (Sherr \& Sherr 1987), and there are even observations on flagellate preferences for living rather than heatkilled bacteria (Landry et al. 1991). We also found some evidence of certain ciliates being able to distinguish between starch particles and algal food. The peritrich ciliate Vorticella $\mathrm{sp}$. was often seen in our samples, but we never found any starch particles in the cells. However, starch seems to make at least as good a substitute for living food as any of the other particles mentioned above. The clearance rates obtained using our method agree well with data obtained using various other methods, and this gives us an indication that the oligotrichs we studied do not reject starch particles due to their repellent chemical or physical surface properties. For heterotrophic dinoflagellatellates, the use of particles probably causes problems because of the extracellular digestion of many dinoflagellates (Gaines \& Taylor 1984).

One problem in grazing studies based on the numbers of ingested particles is the possibility that fixation could cause particle rejection (Sieracki et al. 1987). We found no indications that this phenomenon would have been a serious problem in our study. The ciliates fixed with acid Lugol's solution were, in spite of the low concentration used, mostly in good condition, and no severely disrupted cells were encountered. This evidence, implying good particle retention, is of course circumstantial, and there may be some loss, of at least the largest particles, due to cell shrinkage at fixation. We observed a few specimens of Strobilidium sp. $40 \mu \mathrm{m}$ with a ruptured cell membrane, and a large starch particle partially protruding out of the opening.

The idea of using starch particles in the quantification of ciliate clearance rates and particle size selection originates in the works of Heinbokel (1978a, b). However, the use of food particle suspension consisting of particles of different sizes, with a distinct size distribution, is to our knowledge a novel approach in the study of ciliate feeding. The use of a natural starch particle mixture in ciliate grazing studies has, according to our experience, several advantages. The main benefit appears to be the simultaneous in situ measurement of clearance rates and particle size selection of natural ciliate assemblages, with a minimal effort put into running the experiments, which could make the technique suitable for routine grazing studies. The method is not dependent on measurements of some natural variable that can be attributed only to a certain part of the available food organisms (like chlorophyll a to phytoplankton; e.g. Landry \& Hassett 1982), but should measure total ingestion of particles of different sizes (including heterotrophic organisms). Neither does the method involve the use of highly dangerous chemicals or radioactive substances. One main drawback is the unavoidable laboriousness of the microscopy work. It is unfortunate that the starch granule size distribution (and visibility of small starch particles) is not suitable for studying grazing on bacteria, and that not all ciliates seem to readily ingest starch particles, but in the future this problem should be overcome by the use of fluorescently labelled bacteria and picoalgae parallel to the starch particle experiments.

Acknowledgements. The authors express their gratitude to the other members of the project Pelag, whose mental support has been invaluable. Without the help of the staff of the Tvärminne station things would never have run so smoothly. Special thanks to Tarja Katajisto, who helped in sampling under most demanding circumstances.

\section{LITERATURE CITED}

Albright, L. J., Sherr, E. B., Sherr, B. F., Fallon, R. D. (1987) Grazing of ciliated protozoa on free and particle-attached bacteria. Mar. Ecol. Prog. Ser. 38: 125-129

Andersen, P., Sørensen, H. M. (1986). Population dynamics and trophic coupling in pelagic microorganisms in 
eutrophic coastal waters. Mar. Ecol. Prog. Ser. 33: 99-109

Azam, F., Fenchel, T., Field, J. G., Gray, J. S., Meyer-Reil, L. A., Thingstad, F. (1983). The ecological role of watercolumn microbes in the sea. Mar. Ecol. Prog. Ser. 10: $257-263$

Bakker, C., Pfaff, W. J. (1976). Tintinnida from the coastal waters of the S.W. Netherlands. I. The genus Tintinnopsis Stein. Hydrobiologia 50: 101-111

Beers, J. R., Reid, F. M. H. Stewart, G. L. (1980). Microplankton population structure in Southern California nearshore waters in late spring. Mar. Biol. 60: 209-226

Berggreen, U., Hansen, B., Kiørboe, T. (1988). Food size spectra, ingestion and growth of the copepod Acartia tonsa during development: implications for determination of copepod production. Mar. Biol. 99: 341-352

Bernard, C., Rassouldzadegan, F. (1990). Bacteria or microflagellates as a major food source for marine ciliates: possible implications for the microzooplankton. Mar. Ecol. Prog. Ser. 64: 147-155

Bogdan, K. G., Gilbert, J. J., Starkweather, P. L. (1980). In situ clearance rates of planktonic rotifers. Hydrobiologia 73: $73-77$

Børsheim, K. Y. (1984). Clearance rates of bacteria-sized particles by freshwater ciliates, measured with monodisperse fluorescent latex beads. Oecologia 63: 286-288

Burkill, P. H., Mantoura, R. F. C., Llewellyn, C. A., Owens, N. J. P. (1987). Microzooplankton grazing and selectivity of phytoplankton in coastal waters. Mar. Biol. 93: 581-590

Capriulo, G. M., Carpenter, E. J. (1980). Grazing by 35 to $202 \mu \mathrm{m}$ micro-zooplankton in Long Island Sound. Mar. Biol. 56: 319-326

DeMott, W. R. (1986). The role of taste in food selection by freshwater zooplankton. Oecologia 69: 334-340

Fenchel, T. (1980a). Relation between particle size selection and clearance in suspension-feeding ciliates. Limnol. Oceanogr. 25: 733-738

Fenchel, T. (1980b). Suspension feeding in ciliated protozoa: functional response nad particle size selection. Microb. Ecol. 6: 1-11

Frost, B. W. (1975). Treshold feeding behavior in Calanus pacificus. Limnol. Oceanogr. 20: 263-266

Gaines, G., Taylor, F. J. R. (1984). Extracellular digestion in marine dinoflagellates. J. Plankton Res. 6: 1057-1061

Gast, V. (1985). Bacteria as a food source for microzooplankton in the Sclei Fjord and Baltic Sea with special reference to ciliates. Mar. Ecol. Prog. Ser. 22: 107-120

Heinbokel, J, F. (1978a). Studies on the functional role of tintinnids in the Southern California Bight. I. Grazing and growth rates in laboratory cultures. Mar. Biol. 47: 177-189

Heinbokel, J. F. (1978b). Studies on the functional role of tintinnids in the Southern California Bight. II. Grazing rates of field populations. Mar. Biol. 47: 191-197

Heinbokel, J. F. (1979). Studies on the functional role of tintinnids in the Southern California Bight. III. Grazing impact of natural assemblages. Mar. Biol. 52: 23-32

Jonsson, P. R. (1986). Particle size selection, feeding rates and growth dynamics of marine planktonic oligotrichous ciliates (Ciliophora: Oligotrichina). Mar. Ecol. Prog. Ser. 33: 265-277

Kivi, K. (1986). Annual succession of pelagic protozoans and rotifers in the Tvärminne Storfjärden, SW coast of Finland. Ophelia, Suppl. 4: 101-110

Kivi, K., Kaitala, S., Kuosa, H., Kuparinen, J., Leskinen, E., Lignell, R., Marcussen, B., Tamminen, T (1993). Nutrient limitation and grazing control of Baltic plankton community during annual succession. Limnol. Oceanogr. 38 $893-905$
Kuosa, H. (1990). Protozoan grazing on pico- and nanophytoplankton in the northern Baltic Sea: direct evidence from epifluorescence microscopy. Arch. Hydrobiol. 119: $257-265$

Lampert, W. (1974). A method for determining food selection by zooplankton. Limnol. Oceanogr. 19: 995-998

Landry, M. R., Hassett, R. P. (1982). Estimating the grazing impact of marine micro-zooplankton. Mar. Biol. 67: $283-288$

Landry, M. R, Lehner-Fournier, J. M., Sundstrom, J. A., Fagerness, V. L., Steph, K. E. (1991). Discrimination between living and heat-killed prey by a marine zooflagellate, Paraphysomonas vestita. J. exp. mar. Biol. Ecol. 146: $139-151$

Laval-Peuto, M., Rassoulzadegan, F. (1988). Autofluorescence of marine planktonic Oligotrichina and other ciliates. Hydrobiologia 159: 99-110

Lessard, E. J., Swift, E. (1985). Species-specific grazing rates of heterotrophic dinoflagellates in oceanic waters, measured with a dual-label radioisotope technique, Mar. Biol. 87: 289-296

Lynn, D. H. Montagnes, D. J. S. (1988). Taxonomic descriptions of some conspicuous species of Strobilidiine ciliates (Ciliophora: Choreotrichida) from the Isles of Shoals, Gulf of Maine. J. mar. biol. Ass. U.K. 68:639-658

Mullin, M. M., Fuglister Stewart, E., Fuglister, F. J. (1975). Ingestion by planktonic grazers as a function of concentration of food. Limnol. Oceanogr. 20: 259-262

Niemi, $\AA$. (1975). Ecology of phytoplankton in the Tvärminne area, SW coast of Finland. II. Primary production and environmental conditions in the archipelago and the sea zone. Acta Bot. Fennica 105: 1-73

Paranjape, M. A. (1987). Grazing by microzooplankton in the eastern Canadian arctic in summer 1983. Mar. Ecol. Prog. Ser. 40: 239-246

Paranjape, M. A. (1990). Microzooplankton herbivory on the Grand Bank (Newfoundland, Canada): a seasonal study Mar. Biol. 107: 321-328

Pearre, S. Jr (1982). Estimating prey preference by predators uses of various indices, and a proposal of another based on $\chi^{2}$. Can. J. Fish. Aquat. Sci. 39: 914-923

Rassoulzadegan, F., Etienne, M. (1981). Grazing rate of the tintinnid Stenosemella ventricosa (Clap. \& Lachm.) Jörg. on the spectrum of the naturally occurring particulate matter from a Mediterranean neritic area. Limnol. Oceanogr. 26: $258-270$

Rassoulzadegan, F., Laval-Peuto, M., Sheldon, R. W. (1988). Partitioning of the food ration between pico- and nanoplankton. Hydrobiologia 159: 75-88

Rivier, A., Brownlee, D. C., Sheldon, R. W., Rassoulzadegan, F. (1985). Growth of microzooplankton: a comparative study of bactivorous zooflagellates and ciliates. Mar. microb. Food Webs 1: 51-60

Rublee, P. A., Gallegos, C. L. (1989). Use of fluorescently labelled algae (FLA) to estimate microzooplankton grazing. Mar. Ecol. Prog. Ser. 51: 221-227

Scott, J. M. (1985). The feeding rates and efficiencies of a marine ciliate Strombidium sp., grown under chemostat steady-state conditions. J. exp. mar. Biol. Ecol. 90; 81-95

Sherr, E. B., Rassoulzedegan, F., Sherr, B. F. (1989). Bacterivory by pelagic choreotrichous ciliates in coastal waters of the NW Mediterranean Sea. Mar. Ecol. Prog. Ser. 55: 235-240

Sherr, E. B., Sherr, B. F. (1987). High rates of consumption of bacteria by pelagic ciliates. Nature 325: 710-711

Sherr, E. B., Sherr, B. F., Fallon, R. D., Newell, S. Y. (1986). Small, aloricate cililiates as a major component of the 
marine heterotrophic nanoplankton. Limnol. Oceanogr. 31: $177-183$

Sieracki, M. E., Haas, L. W., Caron, D. A., Lessard, E. J (1987). Effect of fixation on particle retention by microflagellates: underestimation of grazing rates. Mar. Ecol. Prog. Ser. 38: 251-258

Smetacek, V. S. (1981). The annual cycle of protozooplankton in the Kiel Bight. Mar. Biol. 63: 1-11

Smetacek, V.S. (1984). Growth dynamics of a common Baltic protozooplankter: the ciliate genus Lohmanniella. Limnologica 15: 371-376

Stoecker, D., Guillard, R. L. L., Kavee, R. M. (1981). Selective predation by Favella ehrenbergii (Tintinnia) on and among dinoflagellates. Biol. Bull. 160: 136-145

Stoecker, D. K., Michaels, A. E., Davis, L. H. (1987). Large proportion of marine planktonic ciliates found to contain functional chloroplasts. Nature 326: 790-792

Stoecker, D. K., Silver, M. W., Michaels, A. E., Davis, L. H. (1988). Obligate mixotrophy in Laboea strobila, a ciliate

This article was submitted to the editor which retains chloroplasts. Mar. Biol. 99: 415-423

Taniguchi, A., Kawakami, R. (1985). Feeding activity of a tintinnid ciliate Favella taraikaensis and its variability observed in laboratory cultures. Mar. microb. Food Webs 1: $17-34$

Turley, C. M., Newell, R. C., Robins, D. B. (1986). Survival strategies of two small marine ciliates and their role in regulating bacterial community structure under experimental conditions. Mar. Ecol. Prog. Ser. 33: 59-70

Utermöhl, H. (1958). Zur Vervollkommnung der quantitativen Phytoplankton-methodik. Mitt. int. Ver. Limnol. 9: 1-38

Verity, P. G. (1986). Grazing of phototrophic nanoplankton by microzooplankton in Narragansett Bay. Mar. Ecol. Prog. Ser. 29: 105-115

Verity, P. G. (1988). Chemosensory behavior in marine planktonic ciliates. Bull. mar. Sci. 43: 772-782

White, J. R., Roman, M. R. (1992). Seasonal study of grazing by metazoan zooplankton in the mesohaline Chesapeake Bay. Mar. Ecol. Prog. Ser. 86: 251-261

Manuscript first received: March 11, 1994

Revised version accepted: December 19, 1994 